\title{
Twenty Years of Microtron Laboratory Activities at CTU in Prague
}

\author{
M. Vognar, Č. Šimáně, D. Chvátil
}

A concise review is presented of the activities at the Prague microtron laboratory, starting with the construction of the first microtron in the Cxechoslovak Republic, covering RE'D connected with the design and building of electron accelerators of this type, applications of electron and bremsstrahlung beams and fields in applied radiation dosimetry, in the study of radiation-induced changes of optical and other physical properties of inorganic and organic substances (e.g., scintillation crystals such as $\mathrm{PbWO}_{4}$, optical fibres, semiconductors), for activation analysis of samples, especially from geological mineral ore prospecting (gold ores and others), for radioisotope production $\left({ }^{123} I\right.$ for medical diagnostic purposes), et cetera. Participation of the microtron laboratory in the education of students of the faculty in various fields of applied dosimetry and other microtron applications is also discussed.

Keywords: microtron design and construction, electron beams, bremsstrahlung,radioisotope production, radiation damage.

\section{Introduction}

From time to time it is useful to recapitulate the history of efforts made in a specific direction of technical development, and to evaluate the achievements. In our case we will look back at the history of building and applying microtrons in the Microtron Laboratory at the Faculty of Nuclear Sciences and Physical Engineering of the Czech Technical University in Prague. Practically with our own hands we built the only circular accelerators, apart from betatrons, to have been constructed in Czechoslovakia.

\section{Microtron MT 22}

The first microtron MT 22 (Fig. 1) was built in the second half of the 1970s [1] in close collaboration with the Laboratory of Nuclear Reactions (nowadays Flerov LNR) of the Joint Institute for Nuclear Research in Dubna (former USSR). The accelerator itself was of the same type as the microtron at the LNR, working on the principle invented by Veksler and improved by S. P. Kapitza. With the exception of the main electromagnet coils and power supply, the acceleration resonant cavities, some parts of the ferrite insulator and high vacuum pumps, transferred to Prague from Dubna, all other

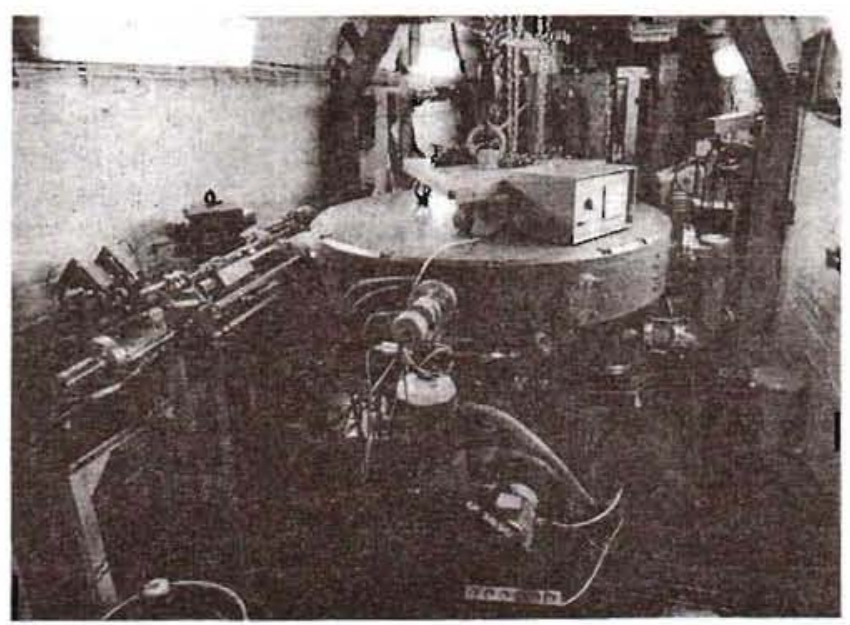

Fig. 1: View on microtron MT 22 from the side of the beam extraction system systems were designed in the Microtron laboratory and manufactured by Czech industry, mostly by ČKD Prague. Two iron yokes were made, one for Prague, and the other for Dubna. The $3 \mathrm{GeV}, 1.8 \mathrm{MW}$ peak power, magnetron high frequency source was taken from a military radar installation and adapted. A new aspect of the Prague microtron design was the original system for extraction of electrons at variable energies (Fig. 2). The maximum energy was set to $22 \mathrm{MeV}$, suitable for routine activation analysis, especially of samples from geological mineral ore prospecting. For analysis of gold ore

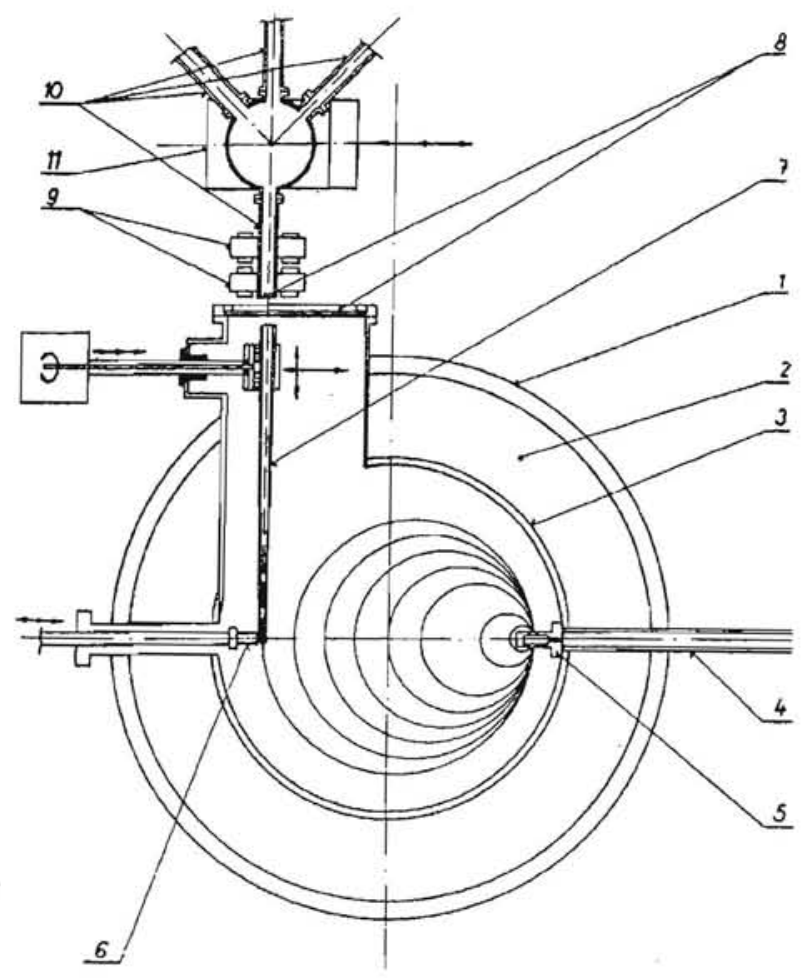

Fig. 2: Plan view of microtron MT 22 and the extraction system. 1-main electromagnet, 2-main electromagnet coils, 3- vacuum acceleration chamber, 4- high frequency line, 5- cavity resonator, 6- current probe, 7- beam extraction channel, 8- thin $\mathrm{Al}$ exit windows, 9- quadrupole doublet, 10- electron beam lines, 11 - bending magnet. 
samples (reaction gamma-gamma prime) an extra $10 \mathrm{MeV}$ extraction channel was introduced in the acceleration chamber. To minimize the costs of shielding against penetrating gamma radiation, a second world war bomb shelter was chosen and adapted for the microtron laboratory. The microtron, situated at the end of a long corridor, required additional concrete shielding with double, heavy shielded entrance doors, only in one direction.

This first microtron came into operation in 1980. A fully-automatized pneu-post for sample transportation and a multiple detector system was designed and made by the collaborating Institute of Mineral Raw Materials in Kutná Hora. Almost one hundred thousand samples of gold-bearing ores, coming from mineral ore prospecting in Czechoslovakia, were analysed during eight years of operation. These radiochemical analyses almost totally occupied the microtron capacity. The rest was used for other radiochemical applications and for improving of the microtron as such.

A second microtron of the same type was built in Czechoslovakia in Kutná Hora, with substantial support from the microtron laboratory, mainly for commercial production of ${ }^{123}$ I for medical purposes. Due to the organizational and other changes at the Institute of Mineral Raw Materials in recent years, this microtron was disassembled.

\section{Chamberless microtron MT 25}

After ten years of successful operation, the microtron MT 22 at CTU was replaced between 1989 and 1991 by the new, so called chamberless type MT 25 [2], jointly proposed in the framework of Prague-Dubna collaboration, covered by a Czech patent certificate [3]. It has the advantage of eliminating the need for a distinct and very complicated vacuum acceleration chamber, the vacuum iron yoke of the main electromagnet replacing the acceleration chamber (Fig. 3). This solution reduces to a minimum the number of vacuum

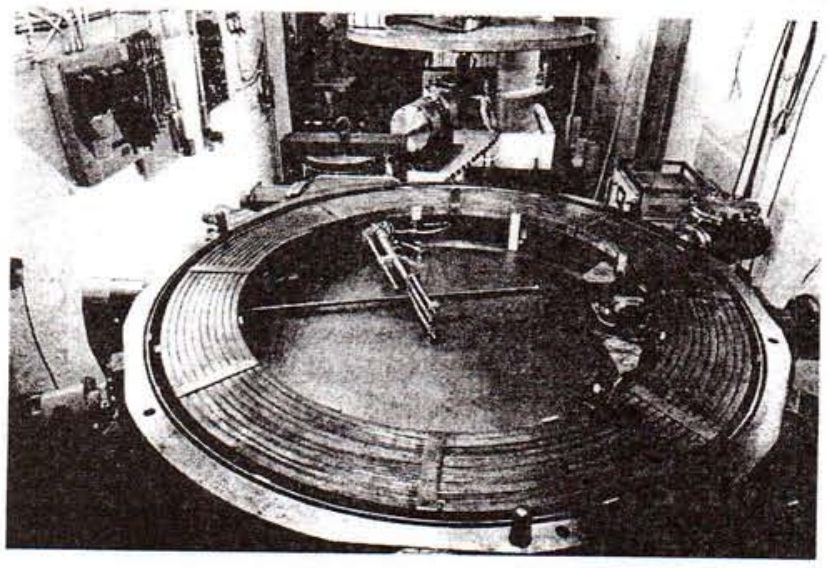

Fig. 3: Insight in the open chamberless microtron MT 25

gaskets, which moreover become easily controllable and accessible for replacement. Two iron yokes, designed at the Prague microtron laboratory, were made by ČKD Prague, one of which was sent to Dubna. The construction of the chamberless microtrons in Prague and Dubna was possible due to the availability from Soviet industry of hollow copper leads for inner water cooling, encased in a vacuum tight copper envelope, mutually isolated by $\mathrm{Al}_{2} \mathrm{O}_{3}$. A pair of coils was made in Dubna for Prague. Although the coils, situated inside the vacuum tight iron yoke, significantly increase the pumped surfaces, experience proved that an operational vacuum can be achieved. At the present time, several nearly identical chamberless microtrons (Fig. 4) are in exploitation, one of them in Prague, another in Dubna. They differ mainly in the beam extraction and beam transport systems.

External step motors are used in the Prague extraction system for two separate movements of the telescopic iron extraction channel, remotely controlled by absolute electromechanical turn encoders [4], also developed in the microtron laboratory. The electron beam is guided by a beam transport

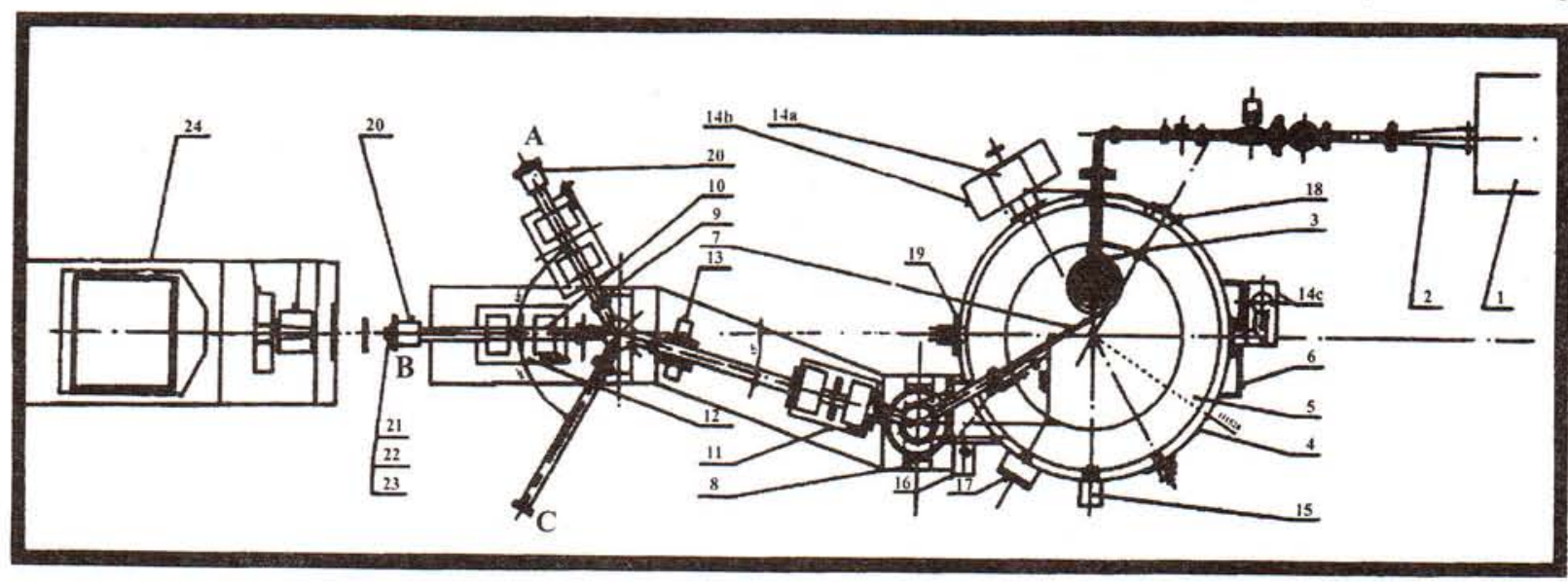

Fig. 4: Microtron MT 25 facility of the Faculty of Nuclear Sciences and Physical Engineering in Prague. 1- HF power input (3 GHz, peak power $2 \mathrm{MW}$, pulse length 2.5 microseconds, pulse repetition rate $400 \mathrm{~s}$-1), 2- wave guide, 3- cavity resonator, 4- electromagnet with vacuum tight magnetic yoke, 5- main coils, 6- electromagnet current supply, 7- beam extraction channel, 8 - bending magnet D1, 9- bending magnet D2, 10- electron beam line, 11- first quadrupole doublet, 12- quadrupole doublets of individual beam lines, 13- steering vertical magnets D3, 14a,b,c- vacuum valve, ion pump, turbo molecular pump, 15- drive for angular displacement of the extraction channel for orbit selection (stepping motor, absolute digital encoder), 16-drive for adjusting the length of the extraction channel (stepping motor, absolute digital encoder), 17- vacuum bushings of magnet coils current leads, 18- cabling vacuum bushings, 19- vacuum gauges, 20- beam mean current and beam position induction pick up, 21-vacuum exit window (Al foil $0.1 \mathrm{~mm}$ ), 22- electron beam diaphragm for gamma fields, 23- electron beam diaphragm Al $30 \mathrm{~mm}$, aperture $2 \mathrm{~mm}$ for electron fields, 24- metrological workstation. 
system to one of three selectable workplaces. Two of them are provided with an induction pick up system for continuous mean electron current measurement and for beam position control close before the beam exit [5]. A system for automatic stabilization of the beam position, close behind its exit to the air through the thin $\mathrm{Al}$ foil, has been installed, using secondary electron emission from thin wires placed at the periphery of the electron beam. The main advantage of this system consists in the fact that the wires absorb a negligible portion of the electron energy and therefore need no supplementary cooling (Fig. 5). The same principle has been proposed and already experimentally tested, for beam position control at

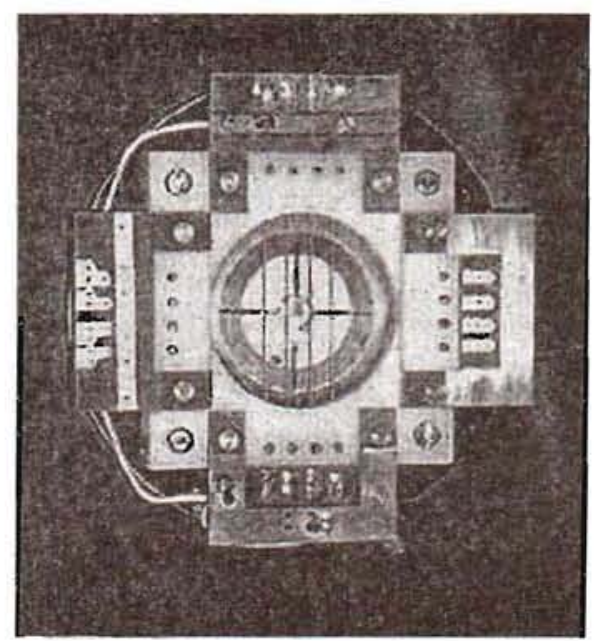

Fig. 5: Front view on the wire pick up system for automatic stabilization of the exit electron beam critical points of the electron transport system, such as the entry orifice of the extraction channel, the entries to the deflecting dipole magnets and magnetic quadrupole lenses. To prevent deterioration of the beam quality by scattering on the pick up wires, they will be made retractable from the beam path.

\section{Microtron beam applications}

An internal beam was obtained from the new microtron in 1990, and an external beam in 1991. Most of the applications were oriented to radiation dosimetry. The idea was to establish in the Czech Republic a secondary standardization laboratory, using standard high-energy electron and gamma fields, for calibrating dosimeters from oncology departments. Supported by the Grant Agency of the Czech Ministry for Industry and Commerce, an experimental arrangement (Fig. 6) was installed [7], consisting of an optical bench with a water phantom and an optically centred collimator system with sets of interchangeable bremsstrahlung filters and scattering foils. The measuring part included a set of ionisation chambers calibrated at the state metrological institute. The arrangement enabled radiation beams with a high quality index (Fig. 7) to be obtained, and homogeneous $10 \times 10 \mathrm{~cm}^{2}$ photon and electron fields precise to $65 \%$ to be generated, complying with the ICRP LAEA standards (Fig. 8) [8]. Lack of funding and the requirement to dedicate the microtron exclusively for dosimetric metrology, which was an unacceptable condition for the faculty, forced the laboratory to abandon this project and to work on other physical and pedagogical applications.

One option was to use the installed experimental arrangement to study radiation induced effects in a range of

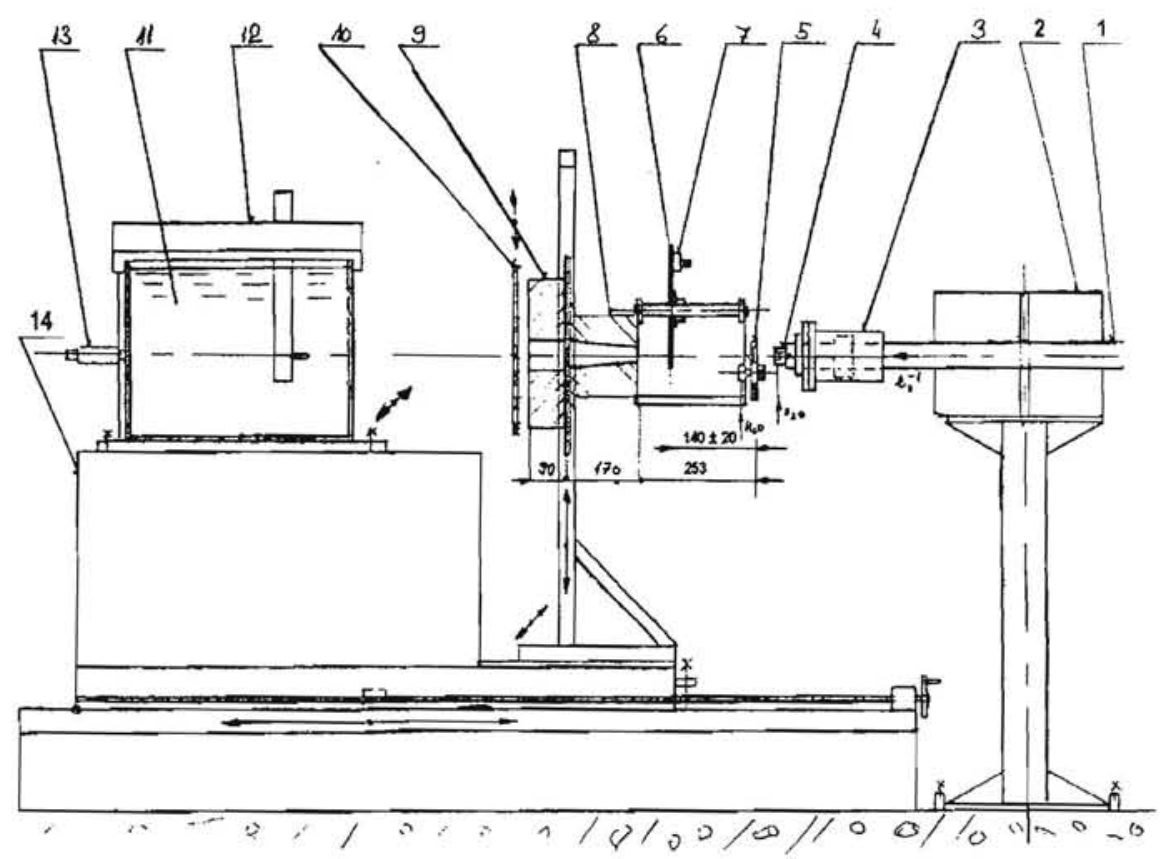

Fig. 6: Scheme of the installation in the beam path for dosimetric applications and for irradiation in well defined electron or bremsstrahlung fields (from ref. 7.) 1- electron beam line, 2- quadrupole doublet, 3- beam mean current and beam position induction pick-up, 4- diaphragm 5- first indexed turret with two W targets 1.5 and $3 \mathrm{~mm}$ and one $\mathrm{Sn}$ foil $0.2 \mathrm{~mm}$, second indexed turret with combined Al-Cu scattering foils, 7- light source, 8-primary conical stainless collimators, 9-secondary rectangular W-steel collimator, 10- third turret with scattering foils, 11- water phantom on mobile support, 12- two-dimensional scanning system THERADOS, 13- laser, support table with water storage tank under the optical bench. 
a)

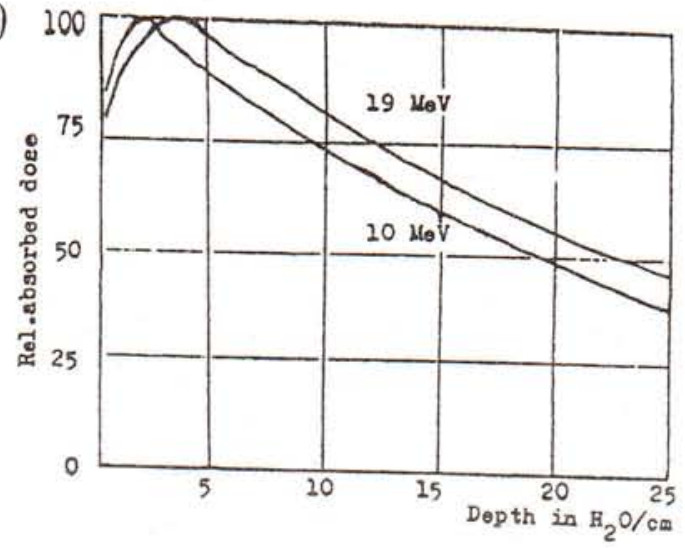

b)

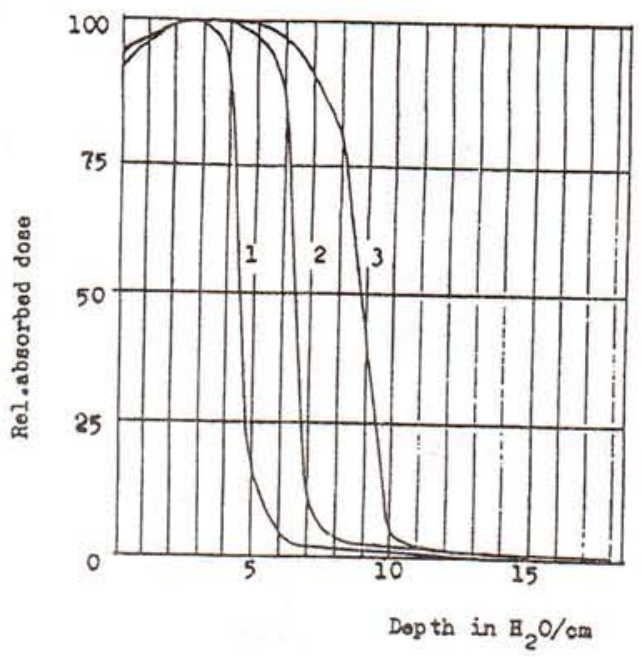

Fig. 7: Depth absorbed dose measurements in the water phantom (from ref 8.). a) central axis depth absorbed dose distribution for maximum photon energies $10 \mathrm{MeV}$ and $19 \mathrm{MeV}\left(\mathrm{SSD}-1 \mathrm{~m}\right.$, field size $10 \times 10 \mathrm{~cm}^{2}$ ), b) relative central axis depth absorbed dose curves for three electron beams energies: $1-9,8 \mathrm{MeV} ; 2-14,6 \mathrm{MeV} ; 3-18,7 \mathrm{MeV}$ (field size $10 \times 10 \mathrm{~cm}^{2}$ )

materials, which also required well defined radiation fields with well known radiation doses and dose rates. Attention was primarily paid to optical changes induced in scintillation crystals, such as $\mathrm{PbWO}_{4}, \mathrm{BGO}$, YAP, used in big detector systems, e.g., the ATLAS electromagnetic calorimeter at CERN.

For this purpose the installation was supplemented with additional parts specially developed and installed for optical spectrometry in the wavelength range from 300 to 800 nanometers, to measure the light transmission coefficient of the crystals [9]. To maintain a constant temperature during the experiments, a special thermostat with Peltier elements was built with forced air circulation in the irradiation volume (Fig. 9). Today, the arrangement is mainly used for testing the irradiation effects in various types of scintillation crystals [10], [11], [12], [13], (Fig. 10), ordered by the manufacturer in cooperation with the Technical University in Liberec. For

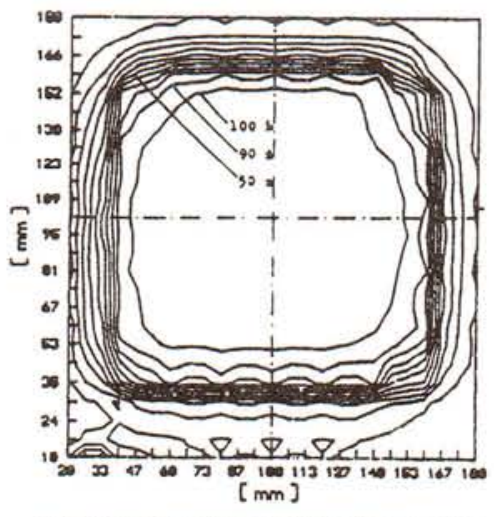

Isoduse plot of the electron fieid $E_{v}=14.6 \mathrm{MeV}$ a at $3.5 \mathrm{~cm}$ depth in water phantom.

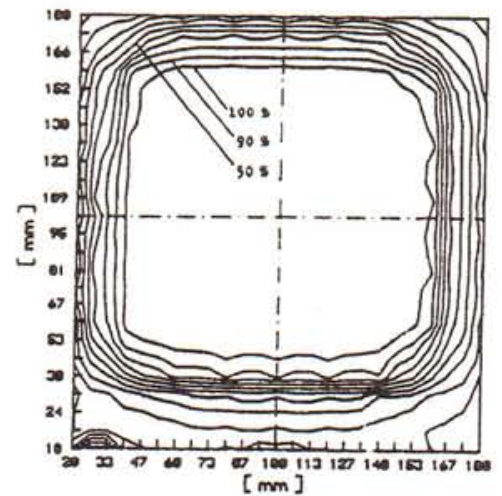

Isovose plot of the electron field $E_{u}=18.7 \mathrm{MeV}$ at a $4.5 \mathrm{~cm}$ depth in waler phantom.

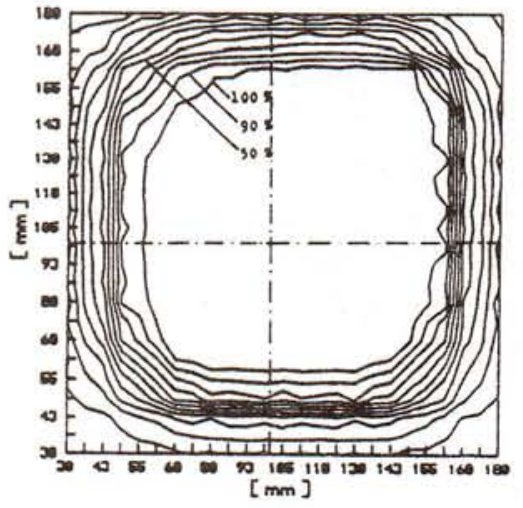

Isodase plot of the photon field $\varepsilon_{\mathrm{u}}=10 \mathrm{MeV}$ at a $10 \mathrm{~cm}$ depth, measured in water phantom.

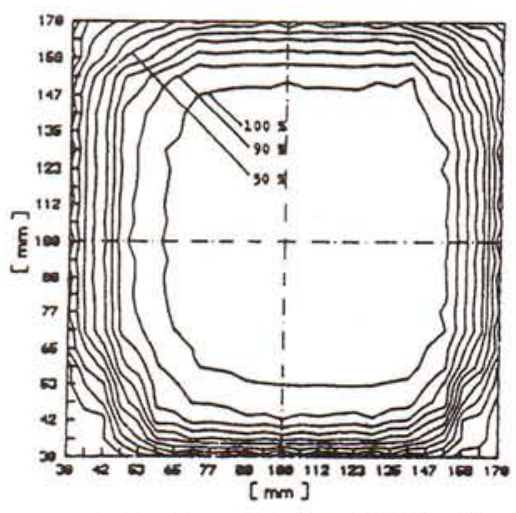
lsudose plot of the photon field $E_{n}=19 \mathrm{MeV}$ ot $210 \mathrm{~cm}$

Fig. 8: Isodose plots of electron and photon fields $10 \times 10 \mathrm{~cm}^{2}$ in the water phantom (from ref. 8) 


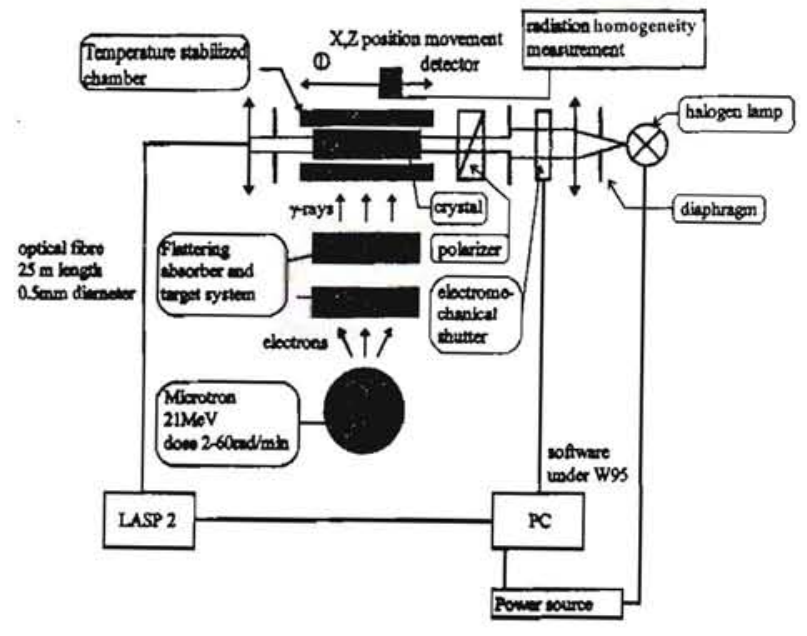

Fig. 9: Experimental arrangement for on-line spectral measurement of light transmission in crystal samples irradiated in bremsstrahlung fields during irradiation and recovery time (from ref. 11)

\section{YAP08, 0,33 Gy/min}

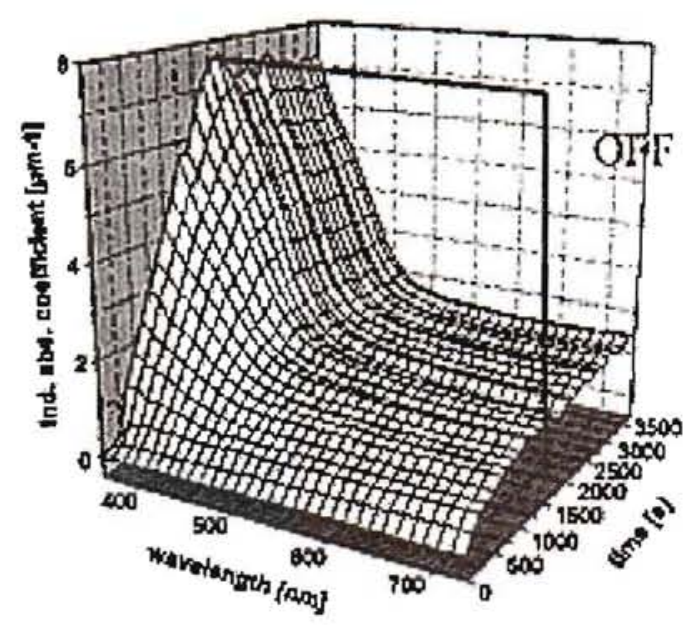

Fig. 10: Spectral linear absorption coefficient of a YAP crystal irradiated by bremsstrahlung from $22,7 \mathrm{MeV}$ electrons versus time of irradiation and recovery time

different radiation dose rates of high-energy bremsstrahlung the light transmission changes are studied during irradiation and in the recovery period after the end of irradiation.

The same on-line arrangement was also used to study the radiation changes in different types of optical fibres [14] (pure fibre, scintillation fibres, shiftered fibres) in high intensity bremsstrahlung fields, close to the e-gamma converter with dose rates up to $10 \mathrm{~Gy} / \mathrm{s}$. (Fig. 11).

Besides the applications cited above, in some individual cases tests were made of the radiation effects in other materials (polystyrene and polyethylene radiation modifications) and radiation hardness of electronic elements and circuits.

For an experimental study of radiation changes in solid-state samples during irradiation by high integral electron fluxes (covering the range from $10^{9}$ to $10^{16}$ electron $/ \mathrm{cm}^{2}$ ) at different energies up to $22 \mathrm{MeV}$, a special facility for absolute electron flux measurement was installed [15]. It consists of a Faraday cup, constructed specially for this purpose in the laboratory, fixed on a telescopic optical bench (Fig. 12), and connected by a triaxial cable with a Keithley electrometer in the control room. The required form of the energy spectrum of the electron fields is produced by combining several scattering foils inserted in the electron flight path [16]. The facility enables irradiation of samples under well-defined electron fields with precise integral flux measurements.

The Faraday cup will also be used for measuring integral electron fluxes when preparing polarized $\mathrm{Li}^{6} \mathrm{D}$ targets in the framework of collaboration between JINR, Charles University and the Czech Technical University in Prague.

A possible microtron application tested in the laboratory in the past was for producing neutrons from gamma-n or from gamma-fission processes. $\mathrm{A} \mathrm{MnSO}_{4}$ bath was used to determine the total neutron yield from a lead or uranium convertor, potentially surrounded by a layer of heavy water. The experimentally determined neutron yields were in the order of $10^{11} \mathrm{~s}^{-1}$ in the $4 \pi$ solid angle. After moderation, the thermal neutron flux near the convertor was about $10^{12} \mathrm{~m}^{-2} \mathrm{~s}^{-1}$.

A further line of applications was the experimental production of radionuclides for labelling some pharmaceutical medical products. This direction had been seriously considered since the start of the first microtron. The main field of interest was the production of ${ }^{123} \mathrm{I}$. Soon after the start of the first microtron, a glass apparatus was assembled in cooperation with the Physical Institute of the Czechoslovak Academy of Sciences, containing a target permanently cooled by liquid nitrogen. Together with the Institute of Mineral Raw Materials in Kutná Hora, several experiments were performed in the late of 1980 s, using natural xenon with the aim to assess the attainable yield of ${ }^{123} \mathrm{I}[17]$. Limited financial resources of both the Prague faculty and the Kutná Hora institute prevented the implementation of experiments with gas enriched in ${ }^{124} \mathrm{Xe}$ content.

In the first half of the 1990s, supported by the Grant Agency of the Czech Republic, the laboratory was in a position to construct a target supplemented by a stainless steel filling and recycling apparatus, using cryogenic pumping [18]. After the first verification experiments with natural xenon gas, tests were carried out with xenon enriched to $11 \%$ [19]. The aim of these experiments was to check which the parameters were important for commercial production, such as the ${ }^{123} \mathrm{I}$ yield, optimum electron energy, optimum irradiation time and post irradiation die out period, effective washing out procedure of the irradiation product, its radiochemical purity, production reproducibility, and so on (Fig. 13).

Calculation of ${ }^{123} \mathrm{I}$ production yield, determination of optimum length of irradiation to get maximum concentration of this radioisotope after the end of irradiation, and the length of the die out period, enabled the laboratory to define economic irradiation conditions, taking into account the necessary radiation protection of personnel during the experiments.

Today the apparatus is still used for pumping and filling defined quantities of the enriched gas to other apparatus. The know-how gained in constructing and exploiting this pilot apparatus was used to advantage by the microtron labo- 

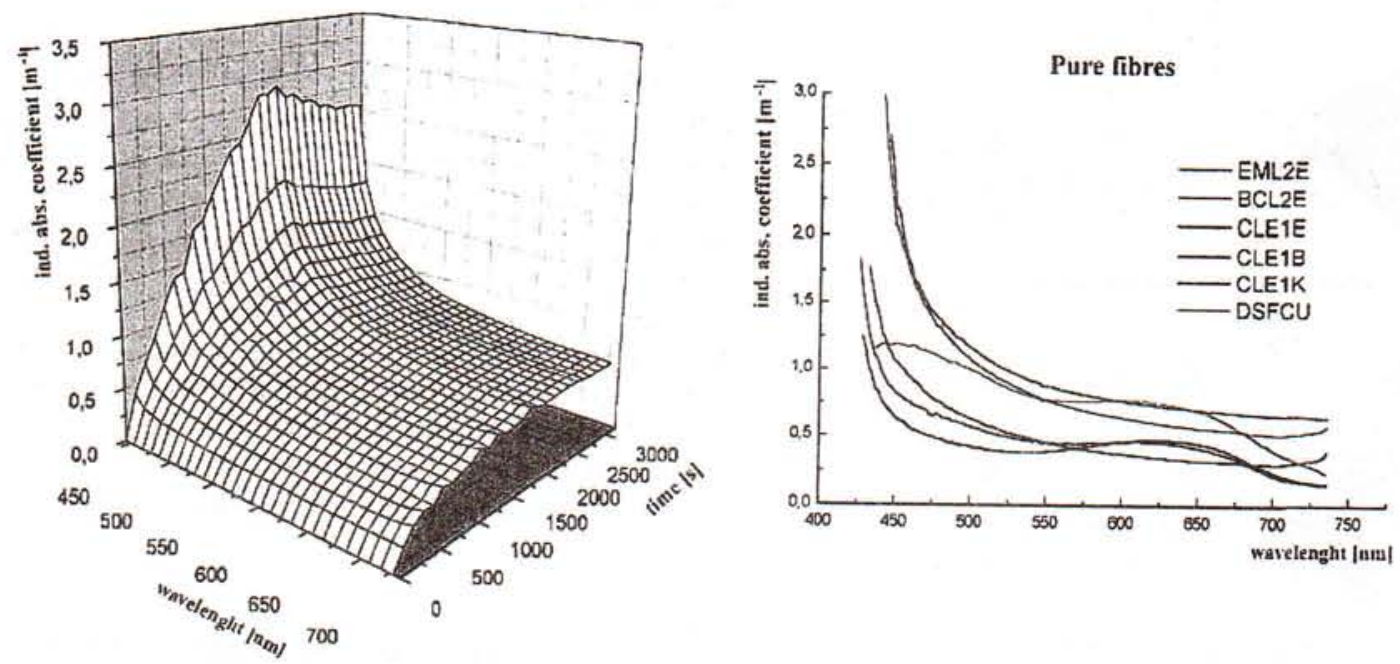

Pure fibres (dose rate $4.185 \mathrm{~Gy} / \mathrm{s}$, total dose $7.533 \mathrm{kGy}$ )
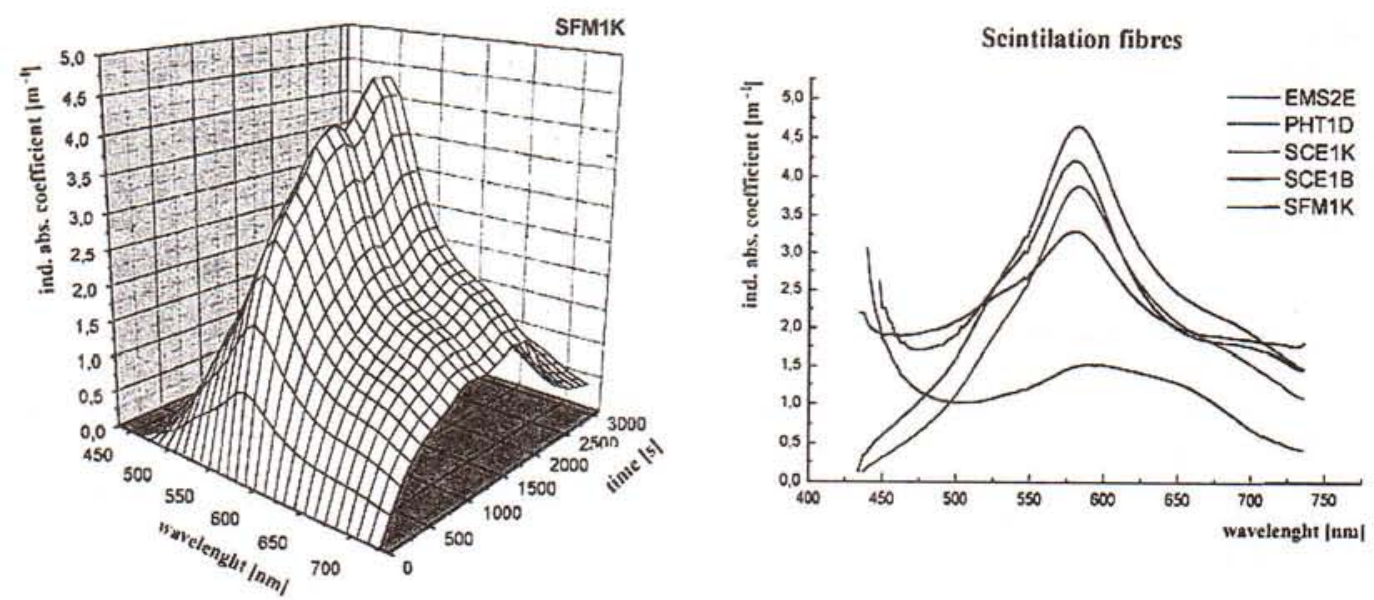

Scintalation fibres (dose rate $4.185 \mathrm{~Gy} / \mathrm{s}$, total dose $7.533 \mathrm{kGy}$ )
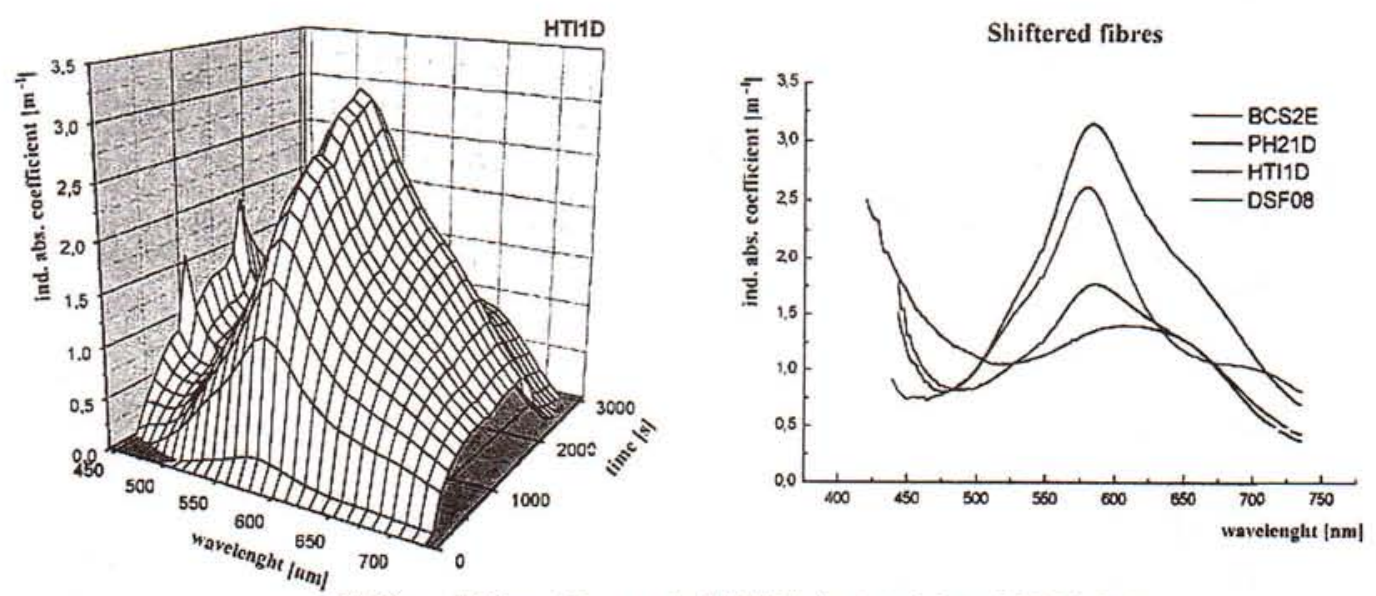

Shiftered fibres (dose rate $4.185 \mathrm{~Gy} / \mathrm{s}$, total dose $7.533 \mathrm{kGy}$ )

Fig. 11: Results of linear absorption coefficients measurements of three types of light fibres irradiated by bremsstrahlung from $22.7 \mathrm{MeV}$ electrons 

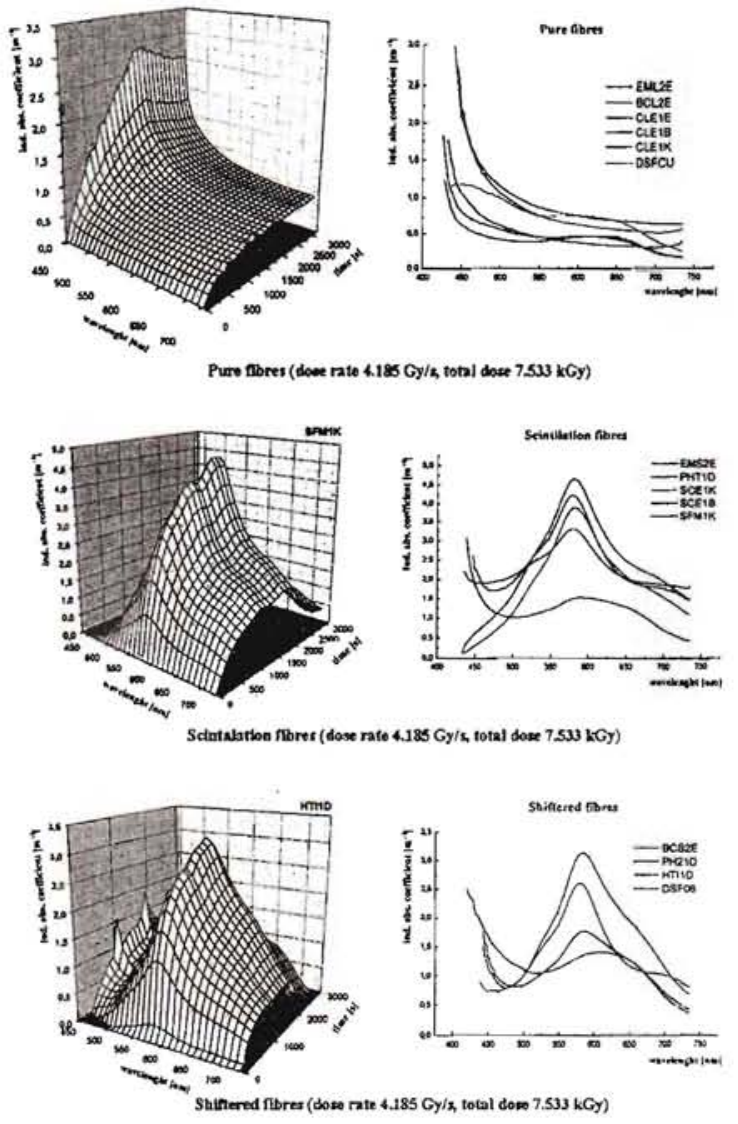

Fig. 12: Experimental arrangement with a Faraday cup for mean electron beam current measurement (from ref. 15) 1- electron beam exit window, 2- Faraday cup entry window, 3- first indexed turret with four diaphragm mounts, 4- second indexed turret with eight diaphragm mounts, 5- conical stainless steel collimator, 6- square W-steel collimator, 7-optical bench, 8-table desk, 9- diaphragm frame, 10 -common platform carriage, 11 -guide rail

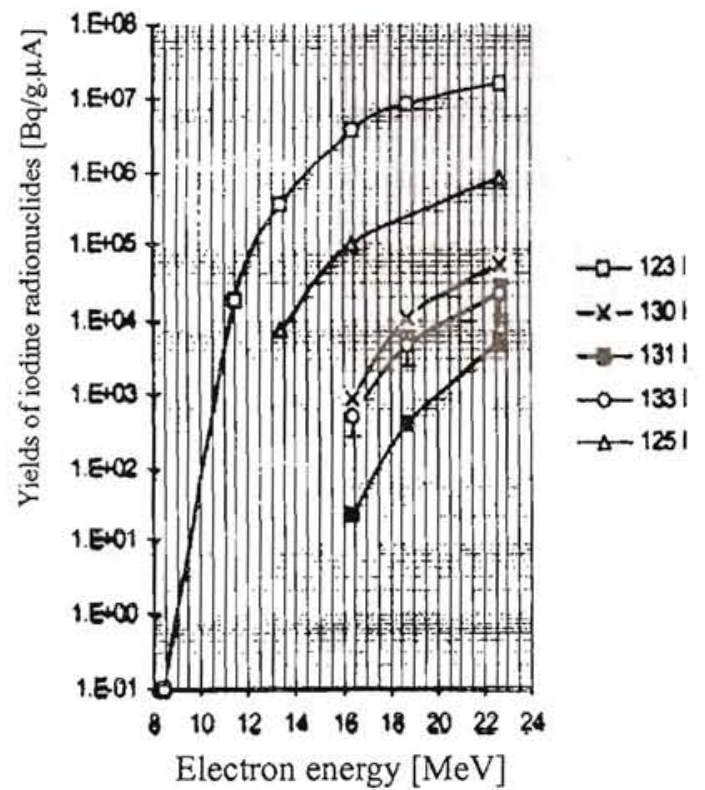

ratory in the design and construction of a production apparatus ordered by the Institute of Mineral Raw Materials in Kutna Hora (Fig. 14).

Meanwhile, new interest in radioisotope production appeared from the Nuclear Physics Institute of the Czech Academy of Sciences at Řež, which asked the microtron laboratory to construct several plants for ${ }^{123} \mathrm{I}$ production and for production of Rubidium-Krypton generators at the cyclotron, by irradiation medium pressure gas targets. The experience gained while constructing apparatus for producing ${ }^{123} \mathrm{I}$ by irradiation of high-pressure Xe targets by microtron bremsstrahlung, served as a basis for constructing $\mathrm{Krl}$ [20] and Xel apparatus (Fig. 15), the former for routine production of ${ }^{81} \mathrm{Rb}^{81 \mathrm{~m}} \mathrm{Kr}$ and the latter for ${ }^{129} \mathrm{I}$ at the cyclotron in $\check{\mathrm{Rez}}$ [21]. Today, this production helps to meet the increasing demand from nuclear medicine in the Czech Republic.

\section{Involvement of the microtron laboratory in the education process}

The microtron laboratory has played a very important role in the teaching process, especially in the education of students in fields such as experimental nuclear physics, neutron physics, neutronography, activation analysis, dosimetry, changes of material properties induced by radiation, solid state physics, nuclear chemistry and principles of acceleration technology. About 30 diploma projects in these fields have been performed by students of the faculty in the microtron laboratory. The laboratory is involved in courses for students from abroad organized by the department of dosimetry, and provides a practical opportunity to participate in special microtron applications in radiation dosimetry and activation analysis.

The microtron laboratory is often visited by students of secondary schools and universities and by members of the public.

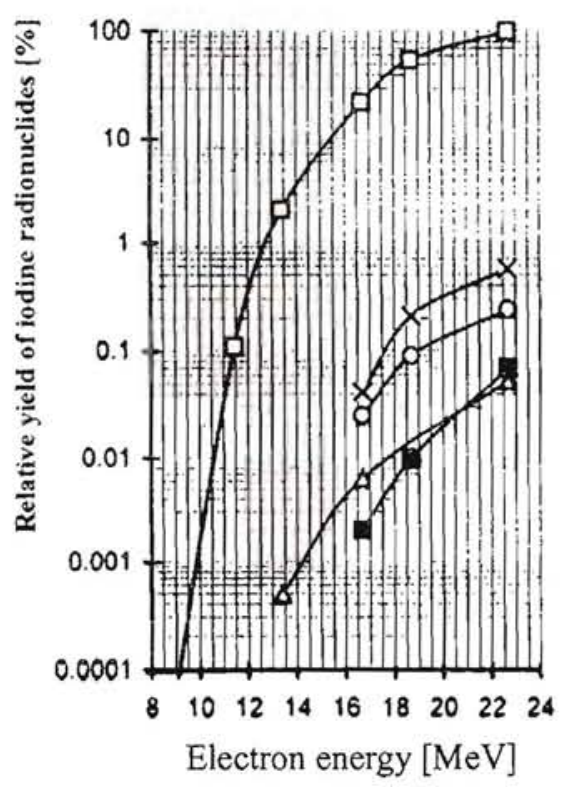

Fig. 13: Yields of iodine radioisotopes from xenon enriched to $10 \%$ in ${ }^{124} \mathrm{Xe}$ content irradiated by bremsstrahlung versus electron energy (from ref. 19) 


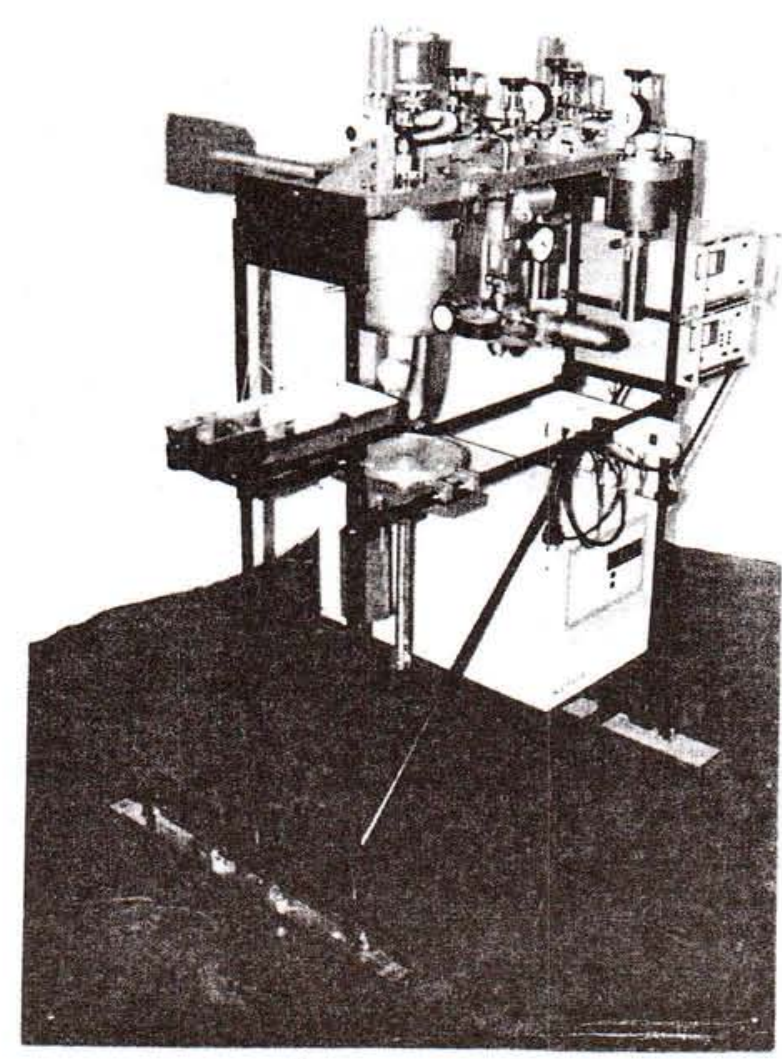

Fig. 14: Apparatus for ${ }^{123}$ I production by photonuclear reactions from ${ }^{124} \mathrm{Xe}$ built in the microtron laboratory for the Institute of Mineral Raw Materials, Kutná Hora

\section{Conclusion}

The microtron laboratory now faces major modernization of the microtron installation, during which the high frequency magnetron generator from the 1960 s will be replaced by a modern one. As a consequence, the microtron will be out of action for some time. An era of the microtron history in the Czech Republic is thus coming to an end. This seemed to us an appropriate moment to summarize twenty years of history of microtron laboratory activities at CTU in Prague.

\section{References}

[1] Šimáně, Č., Vognar, M.: Proní československý mikrotron. JE 27/1981/421-425, JE 28/1982/14-16.

[2] Vognar, M.: Výstavba bezkomorového mikrotronu MT25 na FJFI ČVUT a perspektivy jeho využití. 9. celostátní seminář "Jaderné metody v hornictví, geologii, geofyzice a geochemii" Mariánská u Jáchymova, 1991.

[3] Vognar, M., Belov, A., Šimáně, Č., Pokrovskij, V.: Electromagnet for an Electron Accelerator. ČSFR Patent 239494.

[4] Šimáně, Č.: Absolutní kódování poloh a otáček cyklickými posloupnostmi (Cyclic Sequences and Their Use for Absolute Position and Turn Encoding). Jemná mechanika a optika 2000, No. 1, p. 23-27, No. 2, p. 62-66.

[5] Šimáně, Č., Vognar, M.: Induction Pick up System for Microtron MT25 Current Measuring and Position Indication. WORKSHOP 98, Prague: Czech Technical University, 1998, p. 65-66.

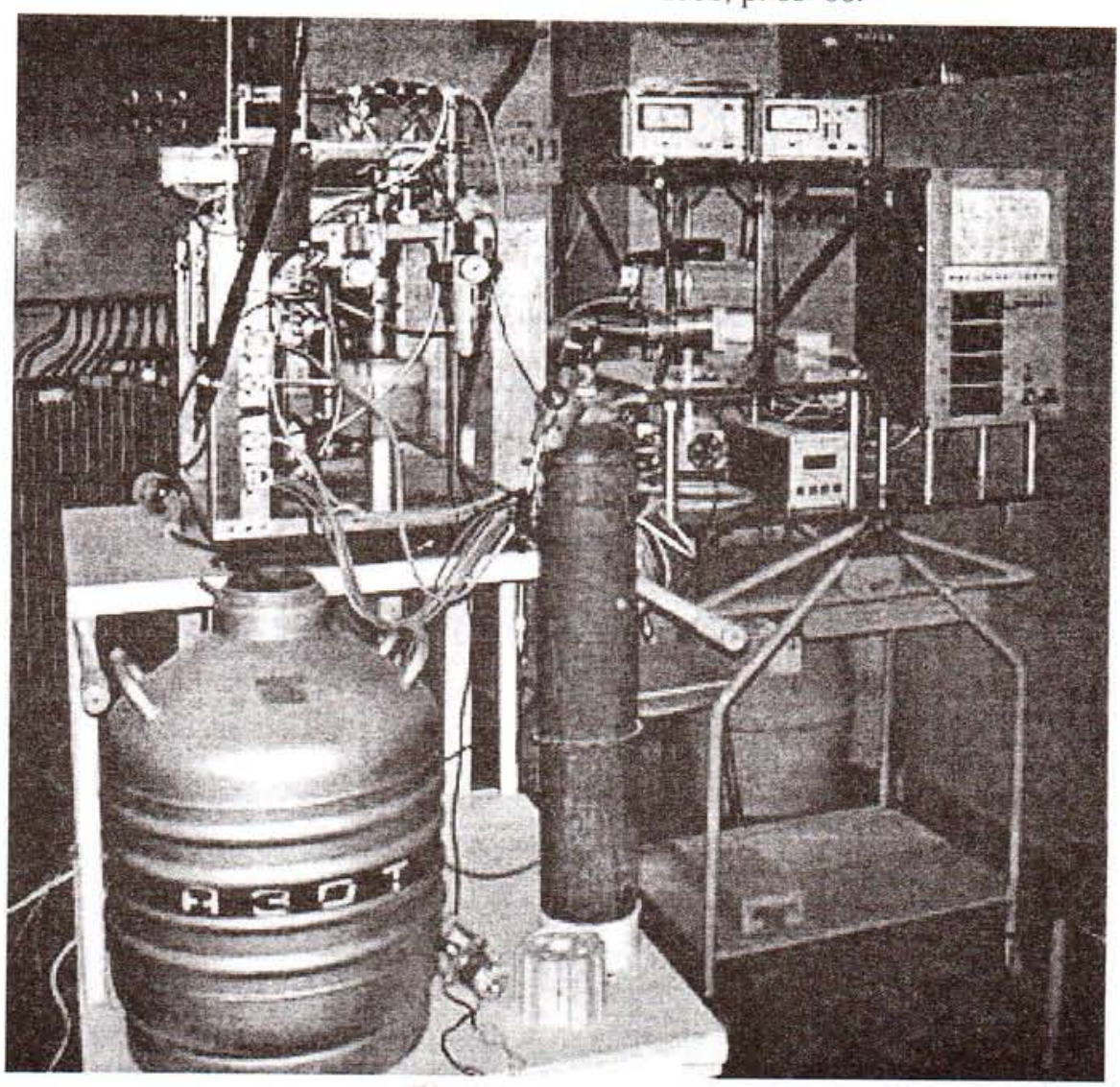

Fig. 15: Apparatus built in the microtron laboratory for ${ }^{123} \mathrm{I}$ production from reactions of protons with ${ }^{124} \mathrm{Xe}$ at the cyclotron of the Institute of Nuclear Physics of the Czech Academy of Sciences at Řež 
[6] Šimánè, Č., Vognar, M., Němec, V.: Stabilisation of Microtron Electron Beam Position. WORKSHOP 2000, Part B, Prague: Czech Technical University 2000, p. 540.

[7] Vognar, M., Novotný, J., Šimáně, Č., Kř́ž, J.: Sekundárni etalonáž wysokoenergetických svazků fotonů a elektronů. Závěrečná zpráva v. ú. ÚNMZ č.M/48/93, Praha, 1993.

[8] Vognar, M., Šimáně, Č., Burian, A., Chvátil, D.: Electron and Photon Fields for Dosimetric Metrology Generaled by Electron Beams from Microtron. Nucl. Instr, and Methods in Phys. Research A 380, 1996, p. 613-617.

[9] Šulc, M., Vognar, M., Šimáně, Č., Finger, M.: Měrené transmise vzorkĩ v radiačním poli gama zár̆ení. Jemná mechanika a optika 1998, No. 10, p. 292-294.

[10] Šulc, M., Vognar, M., Šimáně, Č., Jarolímek, O., Finger, M., Nikl, M., Baccaro, F., Diemoz, M.: Kinetic Model of Color Centres Formation in $\mathrm{PbWO}_{4}$ Crystals. Presented by M. Sulc, Proc. of International Workshop on Tungstate Crystals, Rome, October 12-14, 1998, ISBN 88-87242-10-0, p. 217-221.

[11] Šulc, M., Vognar, M., et al: $\mathrm{PbWO}_{4}$ Crystal Scintilators in Gamma Radiation Field. INTERNATIONAL WORKSHOP "SYMMETRY AND SPIN", Prague, 1998, August 30-September 5.

[12] Šulc, M., Nikl, M., Boháček, P., Nejezchleb, K., Jarolímek, O., Vognar, M.: Gamma-radiation-induced Absorption in Doubly Doped $\mathrm{PbWO}_{4}:$ Mo, $Y$ crystals. Nuclear Instruments and Methods in Physics Research A 486, 2002, p. 345-349.

[13] Šulc, M., Nikl, M., Vognar, M., Nejezchleb, K., Blazek, K.: Kinetics of Induced Absorption Phenomena in $\mathrm{YalO}_{3}$ : Ce Scintilator. Radiation Effects \& Defects in Solids, 2002, Vol.157, p. 963-968.

[14] Blaha, J., et al: Scintilating and Light Guides in Gamma Irradiation Field. Czech. Journal of Physics 50/S1, 2000, p. 387-396.

[15] Vognar, M., Šimáně, Č., Chvátil, D.: Faraday Cup for Electron Flux Measurement on the Microtron MT25. Acta Polytechnica, Vol. 41, 2001, No. 1, p. 11-13.
[16] Vognar, M., Šimáně, Č., Chvátil, D.: Some Aspects of Profiling Electron Fields for Irradiation by Scattering on Foils. Acta Polytechnica, Vol. 41, 2001, No. 1, p. 14-17.

[17] Řanda, Z., Vognar, M.: Možnosti výroby ${ }^{123} I$ pro nukleármi medicinu fotojadernou reakcí z xenonu na čsl.mikrotronu. JE 34/1987/417.

[18] Vognar, M., Šimáně, Č.: Laboratory Apparatus for Preparation of ${ }^{123}$ I from ${ }^{124} \mathrm{Xe}$ by Photonuclear Reaction. Acta Polytechnica, Vol. 36, 1996, No. 5, p. 49-56.

[19] Vognar, M.: The Determination of Maximum Attainable Yield from Reactions with Xe Isotopes by Irradiation of a Liquid Xenon Target. Research report Grant 202/94/0270 GA ČR, 1994-1996.

[20] Vognar, M., Fišer, M., Šimáně, Č., Chvátil, D.: Filling and Recycling Apparatus of a Cyclotron Target with Enriched Krypton for Production of Radiopharmaceuticals. Acta Polytechnica, Vol. 41, 2001, No. 2, p. 3-6.

[21] Vognar, M., Fišer, M., Šimáně, Č., Chvátil, D., Němec, V., Křřž, J.: Filling and Recycling Apparatus of Cyclotron Enriched Kr and Xe Targels for Radiopharmaceutical Production. WORKSHOP 2001, Part B, Prague: Czech Technical University, 2001, p. 770-771.

Ing. Miroslav Vognar

phone: +420222323657, +420224358318

e-mail: vognar@br.fjfi.cvut.cz

Prof. Ing. Čestmír Šimáně, DrSc.

phone: +420224358318

Ing. David Chvátil

Dept. of Dosimetry and Application of Ionizing Radiation

Czech Technical University in Prague

Faculty of Nuclear Sciences and Physical Engineering

Břehová 7

11519 Prague 1, Czech Republic 